\title{
Effects of Using the Scratch Program in 6th Grade Information Technologies Courses on Algorithm Development and Problem Solving Skills
}

\author{
Ali OLUK \\ Kastamonu University Taşköprü Vocational College Medical Services and Techniques \\ Fatih SALTAN \\ Amasya University Faculty of Education Computer and Instructional Technologies
}

\begin{abstract}
This study aimed to identify the effects of using the scratch program in $6^{\text {th }}$ grade information technologies courses on algorithm development and problem solving skills. The study utilized pretest - posttest control group experimental design. A total of 65 (34 control, 31 experimental) $6^{\text {th }}$ grade students in a secondary school in Taşköprü District of Kastamonu Province participated in the study. The study was designed quasiexperimentally. Algorithm Development Test and Problem Solving Inventory developed by Serin et. al. for primary grade students were used as pre and post tests.

Algorithm Development Test: Students were asked four open-ended questions to test their algorithm development skills. The questions aimed to identify skills related to algorithm development, flowchart development, explaining a given algorithm and detecting errors in a given algorithm. A researcher, an information technologies teacher and an instructor undertake the assessment of the Algorithm development test. The Algorithm Development Test score was obtained by taking the average of the three scores. Control group students learned algorithm as presented in the curriculum whereas control group students learned algorithm with the help of the scratch program. Implementation classes received 2-hour Information Technologies instruction per week. The implementation period covered a 6-week process. Results showed no significant differences between the control and experimental groups in terms of algorithm development skills and problem solving skills.
\end{abstract}

Keywords: Scratch, programming education, problem solving skill, visual programming

\section{INTRODUCTION}

Several steps exist in computer programming which can be listed as analysis, design, development and testing (Vatansever, 2011). There are many programming languages which can be used in the development step by the programmer. However, design process precedes

\footnotetext{
* Kastamonu University Taşköprü Vocational College Medical Services and Techniques Department. E-mail alioluk85@gmail.com
} 
program development and compared to the others, individuals with advanced knowledge in programming have been observed to spend more time in mental design activities prior to writing a computer program (Özdinç \& Altun, 2014). It can be argued that when analysis and design steps are not undertaken in a productive manner, the programmer will face many difficulties. Design step should include detailed description of the functions and properties of the program and include a flow chart if possible (Çetin, 2012). It is not sufficient for the programmer to know the programming language to draw a flow chart and to develop algorithms therefore the programmer should have various skills which necessitate training not only in programming languages but also in multi-directional thinking and critical thinking skills. In our country, students who will graduate from primary and secondary level educational organizations are expected to acquire several competences such as critical thinking, multi-directional thinking an decision making skills (MoN, 2006). It can be claimed that students should be provided with training in programming in order for them to acquire the competences listed above. Programming Education is provided for students in Turkish education system at high school level in some departments of vocational schools and at university level in related departments when they choose to study computers. Early opportunities in programming education was found to be effective in providing students with skills such as mathematical thinking and problem solving (Hamada, 1986 cited in: Çetin,2012). Considering the contributions of programming education on students, it can be argued that it should be provided not only at undergraduate level but also at primary and secondary levels in education. Ensuring that the curriculum is based on programming and design will facilitate development of analytical and spatial thinking skills along with problem solving skills (Akpınar \& Altun, 2014).

Students believe that computer programming is a very difficult endeavor which can only be undertaken by the experts with advanced knowledge in codes (Genç \& Tinmaz). This belief may have been originated from the requirement to use several skills together such as abstraction, generalization and critical thinking skills (Gomes \& Mendes, 2007). In order to teach programming, a different structure of thinking should be developed and in order to make the programming process more comprehensible, the concepts and the process should be objectified and concretized (Ersoy, Madran \& Gülbahar, 2011). While designing the courses on programming, several points should be taken into consideration first of which is the selection of the programming language followed by activities that will develop students' problem solving skills and simplify the programming language (Genç \& Karakuş, 2011). Instead of providing students with ready-made and explained codes, they should be provided with the logic of algorithms and programming so that the education can be meaningful (Filiz, Korhan \& Arabacioğlu, 2009). It is believed that using age appropriate and fun programming tools will increase achievement in teaching young children about programming and providing them with the logic of programming. The programming languages created for children such as Scratch, Logo and Smalltalk are designed to be simple and interesting teaching tools (Akçay, 2009). Programs such as Alice ve Scratch are beneficial to ensure that computer programming can be comprehended by all and utilizable by young children (Kaučič \& Asič, 2011). The scratch program is one step ahead of the other programs that can be used in secondary schools in our country since it provides language support and has a website in Turkish (Karabak \& Güneş, 2013). Scratch is a program which allows the acquisition of programming logic and algorithmic thinking skills and it is suggested worldwide for beginners in the area of programming education (Çağıltay Ercil \& Fal, 2013). The program which can be downloaded free of charge from its own website has language support in appproximately 40 different languages. The projects that are uploaded in the Scratch website can be easily downloaded by 
users due to its open source software and communicate with other users without language barriers and to cooperate in developing new projects (Karabak \& Güneş, 2013).

Studies on Scratch generally examined the contributions of the program when used in lessons, student interest towards the program and the contribution of the program in learning programming. The majority of the students who used the program expressed that Scratch was easy, simple and fun to use (Genç \& Karakuş,2011). One of the studies in the field asserted that students who received instruction on programming at early ages had higher mathematical knowledge and problem solving skills (Hamada, 1986 Cited in: Çetin,2012). Providing students with skills such as analytical thinking and problem solving will ensure a more successful programming instruction. It is known that Scratch contributes to the development of mathematical thinking, problem solving, logical growth and analytical thinking (Calder, 2010). Therefore, it is crucial to provide students at early ages with the necessary skills required for programming by the use of Scratch program. A study on the subject presented that use of Scratch improved children's problem solving and algorithm skills (Kaučič \& Asič, 2011). Many examples presented the various positive effects of the Scratch program on children (Genç \& Karakuş, 2011; Çağıltay Ercil \& Fal, 2013; Kaučič \& Asič, 2011). Most of the previous studies generally investigated whether the use of Scratch program affected problem solving and analytical thinking skills. Studies in our country were mostly undertaken at undergraduate level (Genç \& Karakuş, 2011). No studies have been found that focused on the effects of Scratch program on learning algorithms. Current study sought answers to the following question: Does use of Scratch program in $6^{\text {th }}$ grade Information Technologies classes affect the acquisition of algorithm development and problem solving skills?

Sub Problems:

- Does the use of Scratch program in $6^{\text {th }}$ grade Information Technologies classes affect the acquisition of algorithm development skills?

- Does the use of Scratch program in $6^{\text {th }}$ grade Information Technologies classes affect the acquisition of problem solving skills?

- Do algorithm development skills differ according to gender?

- Do problem solving skills differ according to gender?

- Do algorithm development skills differ according to families' monthly income?

- Do problem solving skills differ according to families' monthly income?

\section{METHOD}

Pretest- posttest control group experimental design was used in the study. Experimental method is used to test the effects of researcher-generated differences on the dependent variable and examine cause and effect relationships between variables (Büyüköztürk et all., 2014). While the experimental group was taught by using the Scratch program in Information Technologies classes, the control group used the existing program. Implementation classes received 2-hour Information Technologies instruction per week. The implementation period covered a 6 -week process.

\section{Working Group:}

The working group of the study was composed of a total of 65 students attending $6^{\text {th }}$ grade in Kastamonu province Taşköprü district. Out of this total number, 34 students were included in the control group whereas the remaining 31 was in the experimental group. 
Table 1: Gender Distribution of control and experimental group students

\begin{tabular}{llllll}
\hline \multirow{2}{*}{ Group } & Female & Gender & Male & \% & \multicolumn{2}{c}{ Total } \\
& $\mathbf{N}$ & & $\mathbf{N}$ & & $\mathbf{N}$ \\
\hline Control & 23 & 67,6 & 11 & 32,4 & 34 \\
Experimental & 20 & 64,5 & 11 & 35,5 & 31 \\
Total & 43 & 66,2 & 22 & 33,8 & 65 \\
\hline
\end{tabular}

The control group was composed of 23 female and 11 male students. Female and male students comprised $67,6 \%$ and $32,4 \%$ of the control group respectively. This group utilized the Scratch program in addition to instruction on algorithms and flowcharts.

The experimental group was composed 20 female and 11 male students. Female and male students comprised $64,5 \%$ and $35,5 \%$ of the experimental group respectively. Students in this group were taught algorithms and flowcharts by following the existing program.

\section{Data Collection Tools:}

Students in the experimental and control groups were given Algorithm Development Test and Problem Solving Inventory as pretest and posttest.

Algorithm Development Test: Students were asked four open-ended questions to test their algorithm development skills. The questions aimed to identify skills related to algorithm development, flowchart development, explaining a given algorithm and detecting errors in a given algorithm. The questions prepared before the implementation to determine students' algorithm development skills were reviewed by three experts in the field and necessary modifications were made based on their suggestions. The questions included in the test are provided below:

- Write the algorithm of the program that allows the addition of two numbers written with the help of the keyboard and displays the result on the screen.

- It is assumed that if it is cloudy, an individual takes his/her umbrella while going out whereas he/she does not take it if it is not cloudy. Explain what the individual should do while going out with the help of the flowchart.

- Explain the purpose of the algorithm given below and draw its flowchart.

- Step 1: Start

- Step 2: Write the first number by using the keyboard (x)

- Step 3: Write the second number by using the keyboard (y)

- Step 4: If $x>y$, write "the first number is greater" on the screen

- Step 5:If $y>x$, write "the second number is greater" on the screen Step 6:Write "both numbers are equal" on the screen Step 7:Finish

- The algorithm which provides information about the state of the matter (solid, liquid or gaseous) based on the temperature given as input is presented below. Please check to see if the algorithm contains errors. Explain the error(s) if there are any.

Note:

Note: Water is solid under 0 degree Celcius, liquid between 0-100 degrees Celcius and gaseous above 100 degrees Celcius 
Step 1: Start

Step 2: Write the temperature.(t)

Step 3: If $t>0$, write "solid" on the screen

Step 4: If $t<0$, write "liquid" on the screen, if not write "gaesous"

Step 5: Finish

Problem Solving Inventory: Problem Solving Inventory for Children, developed by Serin et all (2010), was created to test primary grade problem solving skills and self-perception levels. The required factor, validity and reliability analyses of the measurement scale were undertaken. The scale was composed of a total of 3 factors and 24 items and Cronbach Alpha internal reliability value was calculated for each factor separately. Total internal reliability value was calculated to be 0,80 .

\section{Data Analysis:}

Data obtained with Algorithm Development Test were evaluated with the help of scoring rubric. The $4^{\text {th }}$ question in the Algorithm Development Test intended to detect the error in the given algorithm. In order for the students to detect the error, they needed to analyze the algorithm as a whole and find the error. Students who were able to locate the error were given 5 points. Students who were able to correct the error accurately were given another 5 points. The $3^{\text {rd }}$ question asked for the explanation of the algorithm accompanied by a flow chart. Process steps in the flow chart were awarded 4 points while the other steps were awarded 2 points. In explaining the algorithm, students who were able to express the problem as a whole were given 10 points, students who understood the problem but were unable to express is adequately were given 5 points and students who were unable to do neither were given 0 points. $2^{\text {nd }}$ question asks the students to draw a flowchart for the given problem. Students who were able to provide the statement that expressed the condition received 5 points, students who were able to direct the conditions of the statement correctly were given 5 points and all other statements were awarded 2 points. Students who were able to accurately complete the process steps in the $1^{\text {st }}$ question were given 5 points, they were given 2 points when they were able to define a constant in the steps that required value identification whereas they were awarded 1 point if they used expressions such as "write the number" which was not accompanied by identification of the constant. The highest score that can be obtained from the Algorithm Development Test was 75, and the lowest was 0. Assessment of the test was undertaken separately by the researcher, an information technologies teacher and an instructor and the average score was obtained by taking the average of the three scores to find the Algorithm Development Test score.

\section{FINDINGS}

The data obtained in the study were statistically analyzed with the help of SPSS program. Kolmogorov Smirnov Normality test was used to examine the data obtained from control and experimental group students and the findings presented that only the results of problem solving inventory displayed normal distribution whereas the other test results did not. 
Table 2 : Normal Distribution Table

\begin{tabular}{|l|r|r|r|}
\hline \multirow{2}{*}{} & \multicolumn{3}{|c|}{ Kolmogorov-Smirnov } \\
\cline { 2 - 4 } & \multicolumn{1}{|c|}{ Statistic } & \multicolumn{1}{c|}{ df } & \multicolumn{1}{c|}{ P } \\
\hline Algorithm Pre-test &, 245 & 65 &, 000 \\
Algorithm Post-test &, 115 & 65 &, 033 \\
Problem solving Post-test &, 114 & 65 &, 034 \\
Problem solving Pre-test &, 080 & 65 &, $200^{*}$ \\
\hline
\end{tabular}

In order to answer the following question "Does the use of Scratch program in $6^{\text {th }}$ grade Information Technologies classes affect the acquisition of algorithm development skills?", students were given the Algorithm Development Test as pre-test. Mann - Whitney U test was undertaken to check whether significant differences existed between control and experimental groups' Algorithm Development Test results and the data are presented in Table 3.

Table 3. Findings related to experimental and control groups' Algorithm Development Test pretest scores

\begin{tabular}{cccccc}
\hline $\begin{array}{c}\text { Student } \\
\text { Groups }\end{array}$ & $\begin{array}{c}\text { Number of } \\
\text { Samples } \\
(\mathrm{N})\end{array}$ & Mean Rank & Rank Sum & $\mathrm{U}$ & $\mathrm{p}$ \\
\hline Control & 34 & 31,25 & 1062,50 & 467,500 &, 420 \\
Experimental & 31 & 34,92 & 1082,50 & & \\
\hline
\end{tabular}

Examination of the Table shows no significant differences between control and experimental groups' Algorithm Development Test results, U=467,500, p>,05.

In order to answer the following question "Does the use of Scratch program in $6^{\text {th }}$ grade Information Technologies classes affect the acquisition of problem solving skills?" students were given the Problem Solving Inventory for Children. Mann - Whitney U test was undertaken to check whether significant differences existed between the results obtained from control and experimental groups in Problem Solving Inventory for Children and the data are presented in Table 4.

Table 4. Findings related to experimental and control groups' Problem Solving Inventory for

Children pretest scores

\begin{tabular}{cccccc}
\hline Student & $\begin{array}{c}\text { Number of } \\
\text { Samples } \\
\text { Groups }\end{array}$ & Mean Rank & Rank Sum & $\mathrm{U}$ & $\mathrm{p}$ \\
\hline Control & 34 & 36,40 & 1237,50 & 411,500 &, 129 \\
Experimental & 31 & 29,27 & 907,50 & & \\
\hline
\end{tabular}

Examination of the Table shows no significant differences between control and experimental groups' scores obtained from Problem Solving Inventory for Children, U=411,500, p>, 05 .

In order to answer the following question "Does the use of Scratch program in $6^{\text {th }}$ grade Information Technologies classes affect the acquisition of algorithm development skills?", students were given the Algorithm Development Test as post-test. Mann - Whitney U test was undertaken to check whether significant differences existed between control and experimental groups' Algorithm Development Test results and the data are presented in Table 5. 
Table 5. Findings related to experimental and control groups' Algorithm Development Test posttest scores

\begin{tabular}{cccccc}
\hline $\begin{array}{c}\text { Student } \\
\text { Groups }\end{array}$ & $\begin{array}{c}\text { Number of } \\
\text { Samples } \\
(\mathrm{N})\end{array}$ & Mean Rank & Rank Sum & $\mathrm{U}$ & $\mathrm{p}$ \\
\hline Control & 34 & 30,25 & 1028,50 & 433,500 &, 219 \\
Experimental & 31 & 36,02 & 1116,50 & & \\
\hline
\end{tabular}

Examination of the Table shows no significant differences between control and experimental groups' Algorithm Development Test posttest results, $U=433,500, p>, 05$. Hence, it can be claimed that the Scratch program has no significant effects on learning to acquire algorithm development skills.

In order to answer the following question "Does the use of Scratch program in $6^{\text {th }}$ grade Information Technologies classes affect the acquisition of problem solving skills?" students were given the Problem Solving Inventory for Children as posttest. Mann - Whitney U test was undertaken to check whether significant differences existed between the results obtained from control and experimental groups in Problem Solving Inventory for Children and the data are presented in Table 6 .

Table 6. Findings related to experimental and control groups' Problem Solving Inventory for Children posttest scores

\begin{tabular}{cccccc}
\hline Student & $\begin{array}{c}\text { Number of } \\
\text { Gamples } \\
(\mathrm{N})\end{array}$ & Mean Rank & Rank Sum & $\mathrm{U}$ & $\mathrm{p}$ \\
\hline Control & 34 & 35,32 & 1201,00 & 4299 \\
Experimental & 31 & 30,45 & 944,00 & \\
\hline
\end{tabular}

As can be observed from the Table, no significant differences exist between control and experimental groups' Problem Solving Inventory posttest scores, $U=448,000, p>, 05$.. Hence, it can be claimed that the Scratch program has no significant effects on learning to acquire problem solving skills.

Wilcoxon Signed Ranks Test was implemented on both control and experimental groups separately to investigate whether there were meaningful differences in the Algorithm Development Test and Problem Solving Inventory pre and post test scores of the control and experimental groups. Wilcoxon test results for control and experimental groups are provided below:

Table 7: Wilcoxon Signed Ranks Test Results for Algorithm Development Pretest - Posttest for the Control Group

\begin{tabular}{cccccc}
\hline Posttest - Pretest & $\mathrm{n}$ & Mean Rank & Rank Sum & $\mathrm{z}$ & $\mathrm{p}$ \\
\hline Negative Rank & 0 &, 00 &, 00 & 4,861 &, 00 \\
Positive Rank & 31 & 16,00 & 496,00 & & \\
Equal & 0 & & & & \\
\hline
\end{tabular}

Results of analysis present a significant difference between the scores obtained from the Algorithm Development Test for control group members, $z=4,86, p<, 05$. Mean rank for the 
difference scores is in the favor of posttest based on positive ranks. Hence, the study shows the effects of the program in developing algorithms.

Table 8 : Wilcoxon Signed Ranks Test Results for Problem Solving Pretest - Posttest for the Experimental Group

\begin{tabular}{cccccc}
\hline Posttest - Pretest & $\mathrm{n}$ & Mean Rank & Rank Sum & $\mathrm{z}$ & $\mathrm{p}$ \\
\hline Negative Rank & 13 & 13,00 & 169,00 & 1,050 &, 294 \\
Positive Rank & 16 & 16,63 & 266,00 & & \\
Equal & 2 & & & & \\
\hline
\end{tabular}

Results of analysis present no significant differences between the scores obtained from Problem Solving Inventory for experimental group members, $\mathrm{z}=1.05, \mathrm{p}>, 05$.

Table 9 : Wilcoxon Signed Ranks Test Results for Algorithm Development Test Pretest -

Posttest Scores for the Control Group

\begin{tabular}{cccccc}
\hline Posttest - Pretest & $\mathrm{n}$ & Mean Rank & Rank Sum & $\mathrm{z}$ & $\mathrm{p}$ \\
\hline Negative Rank & 0 &, 00 &, 00 & 5,08 &, 00 \\
Positive Rank & 34 & 17,50 & 595,00 & & \\
Equal & 0 & & & & \\
\hline
\end{tabular}

Results of analysis point to a significant difference between the scores obtained from the Algorithm Development Achievement Test for control group members, $\mathrm{z}=2.05, \mathrm{p}<, 05$. Mean rank for the difference scores is in the favor of posttest based on positive ranks. Hence, the study shows the effects of the program in developing algorithms.

Table 10 : Wilcoxon Signed Ranks Test Results for Problem Solving Inventory Pretest -

Posttest for the Control Group

\begin{tabular}{cccccc}
\hline Posttest - Pretest & $\mathrm{n}$ & Mean Rank & Rank Sum & $\mathrm{z}$ & $\mathrm{p}$ \\
\hline Negative Rank & 12 & 21,08 & 253,00 &, 762 &, 446 \\
Positive Rank & 22 & 15,55 & 342,00 & & \\
Equal & 0 & & & & \\
\hline
\end{tabular}

Results of analysis present no significant differences between the scores obtained from Problem Solving Inventory for control group members, $z=, 762, p>, 05$.

In order to answer the following question "Do problem solving skills differ according to gender?", Mann - Whitney U test, which was undertaken to check whether significant gender based differences existed between the results obtained from Problem Solving Inventory for Children post test results and the data are presented in Table 11.

Table 11: Comparison of Problem Solving Inventory Test Results with Mann Whitney U test results according to gender

\begin{tabular}{cccccc}
\hline \multirow{2}{*}{ Gender } & $\begin{array}{c}\text { Number of } \\
\text { Samples } \\
(\mathrm{N})\end{array}$ & Mean Rank & Rank Sum & $\mathrm{U}$ & $\mathrm{p}$ \\
\hline Female & 43 & 34,80 & 1496,50 & 433,500 &, 219 \\
Male & 22 & 29,48 & 648,50 & & \\
\hline
\end{tabular}


As can be gleaned from the results of analysis, there are no significant differences between male and female students in terms of problem solving skills, $U=433,500, p>, 05$.

In order to answer the following question "Do algorithm development skills differ according to gender?", Mann - Whitney U test was undertaken to check whether significant gender based differences existed between the results obtained from Algorithm Development post test results and the data are presented in Table 12.

Table 12: Comparison of Algorithm Development Test Results with Mann Whitney U test results according to gender

\begin{tabular}{cccccr}
\hline Gender & $\begin{array}{c}\text { Number of } \\
\text { Samples } \\
(\mathrm{N})\end{array}$ & Mean Rank & Rank Sum & $\mathrm{U}$ & $\mathrm{p}$ \\
\hline Female & 43 & 35,98 & 1547,00 & 395,500 &, 282 \\
Male & 22 & 27,18 & 598,00 & & \\
\hline
\end{tabular}

Results of analysis point to no significant differences between genders in terms of Algorithm Development Skills, U=395,500, p>,05.

Spearman Brown Spearman Rho Correlation Coefficient data obtained to examine whether there were meaningful differences between Algorithm Development Achievement Test posttest scores and problem solving inventory posttest scores are presented in Table 15.

Table 15: Correlation between Problem Solving Inventory and Algorithm Development Test

\begin{tabular}{|c|c|c|c|c|}
\hline \multicolumn{5}{|c|}{ Correlation } \\
\hline & & & $\begin{array}{c}\text { Algorithm } \\
\text { Achievement Test }\end{array}$ & $\begin{array}{c}\text { Problem solving } \\
\text { Inventory }\end{array}$ \\
\hline \multirow[t]{6}{*}{ Spearman's rho } & Algorithm & Correlation Coefficient & 1,000 & ,224 \\
\hline & Achievement Test & Sig. (2-tailed) & . & 073 \\
\hline & & $\mathrm{N}$ & 65 & 65 \\
\hline & Problem solving & Correlation Coefficient & 224 & 1,000 \\
\hline & Inventory & Sig. (2-tailed) & ,073 & \\
\hline & & $\mathrm{N}$ & 65 & 65 \\
\hline
\end{tabular}

According to the Table, there are no significant differences between Algorithm Development Achievement Test scores and problem solving inventory scores, $r=, 224, p>, 01$.

\section{DISCUSSION}

Results show differences between the arithmetic means of $6^{\text {th }}$ grade control group taught with the help of the regular program $(X=27,17)$ and the arithmetic means of $6^{\text {th }}$ grade experimental group taught with the help of the scratch $(X=32,25)$. Mann - Whitney $U$, utilized to detect if the difference was meaningful, showed no significant differences, $\mathrm{U}=411,500, \mathrm{p}>, 05$.

Related literature includes studies on the effects of programming education on problem solving skills (Çetin, 2012 ; Genç \& Tinmaz; Calder,2010). Among these studies, Genç and Tinmaz found that programming education had not effect on the development of problem solving skills. Current study also support this finding. However, on the contrary, Çetin (2012) and Calder's (2010) studies pointed that programming education affected the development of problem solving skills. 


\section{SUGGESTIONS}

It can be claimed that students in the working groups did not fully comprehend how to generate algorithms and flow charts due to their young ages and that the process was limited to allow the acquisition of these two properties for the given age group. Future studies may be undertaken in longer time frames and include student activities such as writing simple programs after they are taught about algorithms and program samples are provided as support. Activities that will be held to develop problem solving skills can be designed in a manner that will correspond to the stages in problem solving skills. This study can be replicated with the help of a different programming tool developed children and can be implemented on a larger group ina longer time period.

\section{REFERENCES}

Akçay, T. (2009). Perceptions Of Students And Teachers About The Use Of A Kid"s Programming Language In Computer Courses.(Unpublished master's thesis). Middle East Technical University, Ankara.

Akpinar, Y., \& Altun, A. (2014). The deficiency of programming education at the knowledge society school's. [ Bilgi toplumu okullarında programlama eğitimi gereksinimi]Elementary Education Online, 13(1), 1-4.

Büyüköztürk, Ş., Kılıç Çakmak, E., Akgün, Ö.E., Karadeniz, Ş., \& Demirel, F.(2014). Bilimsel araştırma yöntemleri[Scientific research methods]. Ankara: PegemA Pub.

Calder, N. (2010). Using Scratch: An Integrated Problem-Solving Approach to Mathematical Thinking. Australian Primary Mathematics Classroom, 15(4), 9-14.

Çetin, E. (2012). The Effect Of Computer Programming Education On Children's ProblemSolving Skills.(Unpublished master's thesis). Gazi University, Ankara.

Ercil Çağıltay, N., Fal, M. (2014). Scratch ile programlamayı öğreniyorum[Learning to program by using Scracth]. Ankara: ODTU Pub.

Ersoy, H., Madran, R. O., \& Gülbahar, Y. (2011, February). A Model Proposed for Teaching Programming Languages: Robotic Programming. $11 t^{h}$ Academic conference of informatics, Malatya

Filiz, A., Günel, K., \& Arabacığlu, T.(2009,February) The methods to write programs effectively [Etkili Program Yazma Yöntemleri] . 9th Academic conference of informatics, Şanlıurfa

Genç, Z., \& Karakuş, S. (2011). Learning Through Design: Using Scratch In

GENÇ, Z., \& Tinmaz,(2015) H. Evaluation of Students' Problem Solving Skills and Attitude Toward Computers in a Programming Course: A Case Study From Firat. Abstract retrieved from http://perweb.firat.edu.tr/personel/yayinlar/fua_723/723_55601.pdf

Gomes, A., \& Mendes, A. (2007). Learning to program - difficulties and solutions. International Conference on Engineering Education - ICEE 2007. Coimbra, Portugal.

Hamada, R. (1986). The Relationship between Learning Logo and Proficiency in Mathematics. Colombia : Colombia University.

Instructional Computer Games Design. 5th International Computer \& Instructional Technologies Symposium, Elazı $\breve{g}$. Abstract retrieved from http://web.firat.edu.tr/icits2011/icits2011ProceedingBook.pdf 
Karabak, D., \& Güneş, A.(2013). Curriculum Proposal For First Class Secondary School Students In The Field Of Software Development, Journal of Research in Education and Teaching, 2(3), 163-169.

Kaučič, B., \& Asič, T. (2011, May). Improving introductory programming with Scratch?. In MIPRO, 2011 Proceedings of the 34th International Convention, 1095--1100.

MEB(2006). İlköğretim Seçmeli Bilgisayar (1-8. Sinıflar). [ elementary computer electives(18. classes] 03 26, 2015 Abstract retrieved from: http://ttkb.meb.gov.tr/program2.aspx adresinden alınd 1

Özdinç, F., \& Altun, A. (2014). Factors Effecting Information Technology Teacher Trainees' Programming Process. Elementary Education Online, 13(4), 1531-1541.

Serin, O., Bulut Serin, N., \& Saygil1, G. (2010). Developing Problem Solving Inventory for Children at the Level of Primary Education (PSIC). Elementary Education Online, 9(2), 446-458. 